\title{
An economic study of the production of soybean in Egypt
}

\author{
Nagwa El Agroudy \\ Ezzat Awad Zaghlol \\ Soheir Mokhtar \\ Mahmoud El Gebaly \\ Agricultural Economy Department, National research Centre-Cairo, Egypt
}

\begin{abstract}
The Soybean oil is used directly in food and preventing Blood pressure, also Arteriosclerosis. It also contains lot of the essential vitamins for the body, it was started is use in Egypt from the year 1976, it is also a basic source of protein in the poultry and animal feed. The study showed the decrease of the cultivated area with Soya bean with an annual rate statistically signified reached about 2.3 thousand feddan and the stabilization of the feddanic productivity of the yield around the average that reached about 1.216 ton during the period of study (1990-2008), also the cost of production statistically signified reached about 75.8 Pound in the time, the net feddanic revenue increased by an annual rate statistically signified reached about 76.1 pound per feddan which is not representing a buckle to the farmers to cultivate this crop. By studying the production of Maize in Egypt as the essential crop that is competitive for the Soybean crop, it occurred that the decreasing of the cultivated area by Maize in an annual rate not statistically signified reached about 1.046 thousand feddan and decreasing of the feddanic productivity with an annual rate statistically signified reached about 0.285 Ardab/per feddan. Also, the increase of each production costs, farm Price and net revenue of feddan of Maize with an annual rate statistically signified reached about 122.6, 8.9, 138 pound sequently during the period of study. The study showed that the most important variables that affect the cultivated area in Egypt of Soybean are the production costs, farm price and the net revenue for each of Soybean and Maize. The study recommended achieving the projects and policies that lead to increase the cultivated area of Soybean, as the increase of the feddanic productivity, raising the farm price and using the areas that is not cultivated by Rice in cultivating the Soybean instead of maize.
\end{abstract}

Keywords:. - The area of Soy bean, Production costs of Soybean - The feddanic revenue of Soybean - The production of Maize

\section{INTRODUCTION}

The Soybean is considered one of the important food and industrial crops on the international level, owing to containing about $30 \%$ of cholesterol free oil, and about $40 \%$ of protein which is similar in its nourishing value to the animal protein.

The Soy has known from about 7 thousand years, its cultivation began in China and spread it to the South East of Asia and reached Europe in the end of the eighteen the century, its cultivation met a very wide spread.

The Soy oil is one of the most vegetable oils spread, where is used directly in food, preventing from Blood pressure and Arteriosclerosis, also seeds of Soybean contain the most vitamins that are essential for the body, several countries of the world extract different kinds of foods from Soybean as milk and cheese.

The use of Soybean's oil in Egypt had began from the year 1976, the extraction ratio of oil of it is about $20.5 \%$, also it is an essential source of protein in the Animal and Poultry feed.

The problem of the study: In spite of that we suffer from a severe shortage of our needs of the oily crops to the limit that make us import more than $90 \%$ of our needs from edible oils and in spite of reducing the cultivated areas of Rice, it was assumed that these areas to cultivate the oily crops as Soybean, but it was used to expand the cultivation of Maize in spite of excluding of supplying the Maize to the government and reducing the role of the vegetable feed because of closing most of poultry farms, while the cultivation of these areas and part from the areas of Maize and Guinea corn as on oily crops as sunflower and Soybean are capable to achieve good profits to the farmers, also with saving a lot of money of foreign currency we can participate in raising the farm price for the Egyptian farmer instead of paying it to the foreign farmer. 
Aim of the study: This study aims to define the areas, production, feddanic costs, net profit and studying the factors that affect the expansion in its cultivation in Egypt.

The research method and data sources: In this study was used the methods of the descriptive and statistical analysis to estimate the definitions the line regression, the simple and the multiple, also the definition of the step-wise with the line and double logarithmic features.

The study depended on the secondary data that is published and non-published from its different sources as, the agricultural bulletin of economy, the central authority of general mobilization and static's. Also, the internet of information to gain the data serving this study.

\section{The Results of the study}

The production of Soybean in Egypt: The average of imports from the Soybean oil was about 6.91 million tons with an average price of about 537.33 Dollars per ton during the period 1990-2008, the table No. (1) declares that the cultivated area of Soybean was vibrated during the period of study between maximum limit of 62 thousand feddan in the year 1995 and a minimum limit of 9.2 thousand feddan in the year 2000 the equation of trend No. (1) in the table No.(2) shows a decreasing trend statistically signified reached about 2.3 thousand feddan yearly representing about $8.1 \%$ from the average cultivated area of Soybean during the period of study ( 28.5 thousand feddan), this decline it due to the decline of the revenue of the cultivation of Soybean compared with other summer crops.

By studying the productivity of the Soybean crop, it occurs that it is stable almost around the average that was 1.216 ton, during the period of study.

The equation of trend No. (2) in the table No. (2) shows raising trend statistically signified in the productivity of feddan from the Soybean reached about 0.02 ton represents about $1.6 \%$ from the average feddanic during the period of study (1.216 ton).The continuance vibration in the cultivated area with Soybean and its productivity led to the vibration of the total

Table 1 : The Economic Importance for Soybean in Egypt(1993-2008)

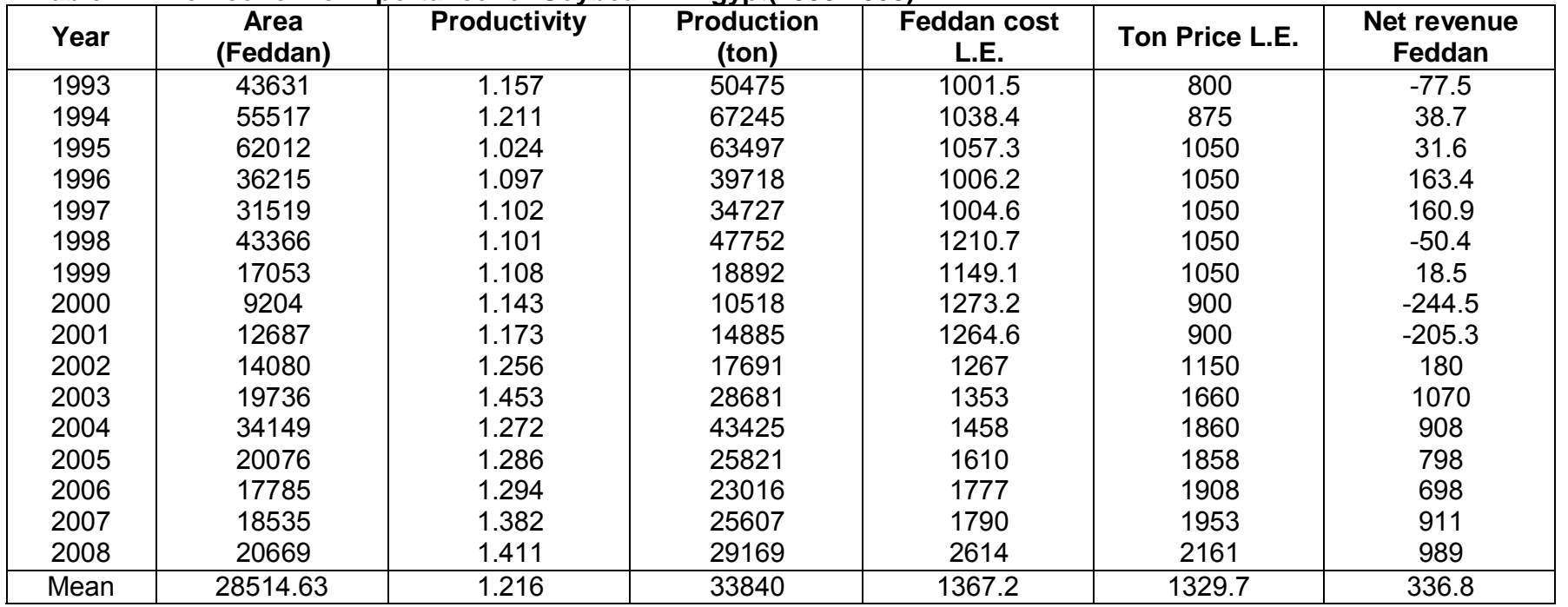

Reference: Ministry of Agric. And land recl. - central administration of agric. Economics and statistics (different volumes).

Table 2: Equations of the trend for Soybean crop in the period 1993-2008

\begin{tabular}{|c|c|c|c|c|c|}
\hline No. & Equation & $\mathrm{R}^{2}$ & $\mathrm{~T}$ & $\mathrm{~F}$ & \%Variation Rate \\
\hline 1 & $\mathrm{Y}_{\mathrm{h}}=48041-2.297 \mathrm{X}_{\mathrm{h}}$ & 0.474 & $3.55-$ & 12.599 & 8.1 \\
2 & $\mathrm{Y}_{\mathrm{h}}=1.04+0.02 \mathrm{X}_{\mathrm{h}}$ & 0.615 & 4.734 & 22.407 & 1.6 \\
3 & $\mathrm{Y}_{\mathrm{h}}=722.92+75.794 \mathrm{X}_{\mathrm{h}}$ & 0.732 & 6.177 & 38.161 & 5.5 \\
4 & $\mathrm{Y}_{\mathrm{h}}=577.7+88.469 \mathrm{X}_{\mathrm{h}}$ & 0.791 & 7.283 & 53.042 & 6.7 \\
5 & $\mathrm{Y}_{\mathrm{h}}=-309.845+76.08 \mathrm{X}_{\mathrm{h}}$ & 0.571 & 4.575 & 20.93 & 22.6 \\
\hline
\end{tabular}

Reference: Calculated from table (1) 
Where:

The production of Maize in Egypt: The Maize Crop $Y_{h}$ is the estimated value for the subsequent variable inis considered the most important summer Crop in the year $h$ )

$\mathrm{X}_{\mathrm{h}}$ is the time variable in the year (h) : $(1,2, \ldots \ldots \ldots, 16)$.

Production of the Soybean crop, between two limits, the maximum was about 67.2 thousand tons in the year 1994 and a minimum of about 10.5 thousand tons in the year 2000, table No. (1). It also occurred from the table No. (1) that the cost of production of the feddan of Soybean was accelerated during the period of study from about 1001.5 pounds in the year 1993 to about 2614 pounds in the year 2008 which represents about $161 \%$ from the year 1993 .

The trend equation No. (3) in the table No. (2), which shows a trend of statistical significant raising reached about 75.8 pound representing about $5.5 \%$ of the average feddanic cost of Soybean during the period of study (1367.2 Pounds).

By studying the price of ton of Soybean during the period of study (1993 - 2008) it was found a stabilization from the year 1995 until 1999 where it reached about 1050 pound per ton, then it declined on the years $2000-2001$ where it reached about 900 pounds per ton, then started to increase till it reached about 2161 pounds per ton in the year 2008 table No. (1).

The equation No. (4) in table No. (2) shows a raising trend statistically signified reached about 88.5 pound representing about $6.7 \%$ from the average price of ton per feddan of soybean during period of study (1329.7 Pound).

By studying the net revenue of the Soybean crop it was found that it was vibrating during the of studying but also it gained a loss in some years as 1993,1998,

2000, 2001

It occurs from the table No. (1) that the feddanic net revenue is very week and don't represent an initiation for the farmer to cultivate that important crop.

The equation No. (5) in table No. (2) shows a statistically significant increased trend reached about 67.1 pound per feddan representing about $22.6 \%$ from the feddanic average net revenue during the period of study (336.8 pound).
Egypt, it is a Competitive Crop to the Soybean crop, where that in spite of the decline of the activity of the vegetative feed factories and the elimination of supplying the Maize crop to the government, but the farmer insist on its cultivation as a result of the rising of its farm revenue than the Soybean crop.

By studying the Numbers mentioned in table No. (3), it occur that the area of Maize was vibrating during the period of study $(1993-2008)$ between two limits, a maximum one reached about 1881 thousand feddan in the year 2005, and a minimum one of 1524 thousand feddan in the year 1999 , it also occur that the feddanic productivity continued to increase till the year 1998 and reached about 23.09 Ardab per feddan, then began to decrease until it reached about

16.88 Ardab per feddan in the year 2008, which was reflected on the production that reached a maximum of 39196 thousand Ardab in the year 1998, then decreased to about 28150 thousand Ardab in the year 2004, then reached about 30152 thousand Ardab in the year 2008.

The equation of the trend No. (1) in the table No. (4) shows statistically non-significant increase in the area of Maize that was about 1.046 thousand feddan representing about $0.06 \%$ from the average area that is cultivated during the period of study (1680 thousand feddan). Also, the equation No. (2) table No. (4) shows a declining trend statistically signified reached about 0.285 Ardab in the feddanic productivity of Maize representing about $1.5 \%$ from the average productivity during the period of study (18.55 Ardab).

By studying the costs of production from the data available for Maize, it is shows that it was an accelerated raise where it was raised from about 950 pound per feddan in the year 1993 to about 3297 pound in the year 2008 with a raise estimated by about $245 \%$ in the year 1993 .

The equation of trend No. (3) table No. (4), shows a statistically signified increased trend reached about

122.617 pound representing about $7.5 \%$ from the average cost of feddan during the period of study (1643.6 pound). 
Agric. Biol. J. N. Am., 2011, 2(2): 221-225

Table 3 :Economic Importance for Maize in Egypt in the period (1993-2008)

\begin{tabular}{|c|c|c|c|c|c|c|}
\hline Year & $\begin{array}{c}\text { Area } \\
\text { 1000/feddan }\end{array}$ & $\begin{array}{c}\text { Productivity } \\
\text { Ardab }\end{array}$ & $\begin{array}{l}\text { Production } \\
\text { 1000/Ardab }\end{array}$ & $\begin{array}{l}\text { Feddan cost } \\
\text { L.E. }\end{array}$ & $\begin{array}{c}\text { Ardab Price } \\
\text { L.E. }\end{array}$ & $\begin{array}{l}\text { Net revenue of } \\
\text { Feddan L.E. }\end{array}$ \\
\hline 1993 & 1661.190 & 18.99 & 31546 & 956 & 64.0 & 353 \\
\hline 1994 & 1739.512 & 20.5 & 35660 & 1005 & 66.7 & 417 \\
\hline 1995 & 1751.379 & 18.73 & 32803 & 1075 & 71.7 & 356 \\
\hline 1996 & 1768.259 & 20.98 & 37098 & 1132 & 75.0 & 543 \\
\hline 1997 & 1636.014 & 22.79 & 37285 & 1113.3 & 77.0 & 751.4 \\
\hline 1998 & 1697.552 & 23.09 & 39196 & 1496 & 81.0 & 493.9 \\
\hline 1999 & 1524.059 & 17.48 & 26641 & 1402 & 85.0 & 743 \\
\hline 2000 & 1570.447 & 17.51 & 27499 & 1430 & 85.0 & 763 \\
\hline 2001 & 1704.424 & 17.41 & 29674 & 1472 & 86.0 & 752 \\
\hline 2002 & 1597.576 & 17.34 & 27702 & 1480 & 88.0 & 824 \\
\hline 2003 & 1602.644 & 17.29 & 27710 & 1709 & 97.0 & 855 \\
\hline 2004 & 1627.145 & 17.30 & 28150 & 1846 & 145.0 & 1935 \\
\hline 2005 & 1881.038 & 17.00 & 31978 & 2055 & 145.0 & 1821 \\
\hline 2006 & 1669.646 & 17.04 & 28451 & 2206 & 151.0 & 1881 \\
\hline 2007 & 1725.328 & 17.01 & 29348 & 2624 & 221.0 & 3051 \\
\hline 2008 & 1786.249 & 16.88 & 30152 & 3297 & 198.0 & 1754 \\
\hline Mean & 1680.096 & 18.55 & 31306 & 1643.644 & 108.525 & 1080.831 \\
\hline
\end{tabular}

Reference: Ministry of Agric. And land recl. - the central administration of agric. Economics and statistics (different volumes).

It also shown from the data of table No. (3) the increasing of the price of Ardab of Maize from about 64 pound in the year 1993 to about 198 pound in the year 2008 with an increase estimated by about $209.4 \%$, that is declared by the equation of trend No.
(4) in the table No. (4) where it shows a statically signified raising trend reached about 8.947 pound representing about $8.2 \%$ from the average price of Ardab during the period of study (108.525 pound).

Table 4: Equations of the genera direction for Soybean crop in the period $1993-2008$

\begin{tabular}{|c|c|c|c|c|c|}
\hline No. & Equation & $\mathrm{R}^{2}$ & $\mathrm{~T}$ & $\mathrm{~F}$ & $\begin{array}{c}\text { \%Variation } \\
\text { Rate }\end{array}$ \\
\hline 1 & $\mathrm{Y}_{\mathrm{h}}=161.1202+1.046 \mathrm{X}_{\mathrm{h}}$ & 0.003 & 0.212 & 0.045 & 0.06 \\
2 & $\mathrm{Y}_{\mathrm{h}}=20.975-0.285 \mathrm{X}_{\mathrm{h}}$ & 0.424 & $3.210-$ & 10.305 & 1.5 \\
3 & $\mathrm{Y}_{\mathrm{h}}=601.395+122.617 \mathrm{X}_{\mathrm{h}}$ & 0.831 & 8.285 & 68.640 & 7.5 \\
4 & $\mathrm{Y}_{\mathrm{h}}=32.472+8.947 \mathrm{X}_{\mathrm{h}}$ & 0.772 & 6.887 & 47.430 & 8.2 \\
5 & $\mathrm{Y}_{\mathrm{h}}=-92.378+138.025 \mathrm{X}_{\mathrm{h}}$ & 0.725 & 6.080 & 36.960 & 12.77 \\
\hline
\end{tabular}

Reference: Calculated from table (3)

Where:

$Y_{h}$ is the estimated value for the following variable in the year $(h) X_{h}$ is the time variable in the year $(h):(1,2, \ldots \ldots, 16)$.

Soybean is concentrated in the governorates of

About the net revenue of feddan, it increased from about 353 pound in the year 1993 to about 751.4 pound in the year 1997, then decreased to about 493.9 pound in the year 1998, then it increased till it reached about 3051 pound in the year 2007, then it decreased to 1754 pound in the year 2008.

The equation No. (5) in the table No. (4) shows an accelerating trend statistically signified reached about 138.025 pound representing about $12.77 \%$ from the net revenue of feddan during the period of study (1080.8 pound).

The Effective factors on the production of
Soybean in Egypt: It is known that the cultivation of Bani-Swaif, El-Menia and Assuit, the area of Maize in these only three governorates about 603.950 thousand feddan that is about 29 double (Times) the area of Soya bean on the governmental level in the year 2008, also the feddan of Maize has achieved about 1.7 double (times) of the Soybean during the year 2008.

The most important factors that affect the production of Soybean is the cultivated area which is affected by several factors, of which, the production costs, farm price and the net revenue of Soybean, also the production costs of Maize and its farm price also the net revenue of it. 
The equation of multi regression is estimated in the line form to show the effect of the different factors on the area of Soybean.

The best result of estimation had been gained as follows.

$$
\begin{aligned}
& Y=-12818.4+69.297 X_{1}-6.885 \times 2+26.081 X_{3}
\end{aligned}
$$

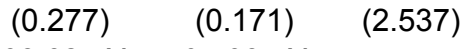

$$
\begin{aligned}
& 2294.697-X_{4}+108.625 X_{5}-95.085 X_{6} \\
& \begin{array}{lll}
(5.281) \quad(3.505) \quad(4.911) \\
\hline
\end{array}
\end{aligned}
$$

Where

$Y=$ the cultivated area of Soybean

$\mathrm{X}_{1}=$ the price of Soybean

$\mathrm{X}_{2}=$ the feddanic cost of Soybean

$X_{3}=$ the feddanic revenue of Soybean

$\mathrm{X}_{4}=$ the price of Maize

$X_{5}=$ the feddanic costs of Maize

$X_{6}=$ the feddanic revenue of Maize

adj $r^{2}=0.85$

$F=9.35$

From this equation it occur the increase of its significance and the value of $\mathrm{R}^{2}$ where, the variables is explained in the price and costs and net revenue of Soybean, also the price and costs and net revenue of Maize all together about $85 \%$ of the variables in the cultivated area of Soybean.

The statistical signification had been ensured for the price of farm and the feddanic revenue of Soybean also, the farm price, the feddanic costs and the feddanic revenue for the Maize crop.

Also, the signs were identified with the Economical sense.

In other trial the previous equation had been estimated in the double logarithmic form and was as follows:

$\log Y=17.03+1.13 \log X_{1}-2.33 \log X_{2}+$ 0.02

$\log$

$\mathrm{X}_{3}$

(3.53) (2.13)

when the decrease in the feddanic costs of Soybean, farm price and the net revenue of Maize by $10 \%$, then the cultivated area of Soybean was increased by $23.3 \%, 37.1 \%$, and $11.3 \%$ sequently

This means that the cultivated area of Soybean crop in Egypt is affected by the changes in the price, revenue and costs of feddan of Maize crop, also is affected by the changes in the price and costs of feddan of Soybean.

As previous study of the production of Soybean in
Egypt, the study can recommend the followings:

1- Paying more interest to achieve the agricultural policies that encourage to increase the cultivated area of Soybean in Egypt.

2- Improving the researches for the production of Soybean to produce other species that achieve more productivity, then it can give higher revenue which encourage the farmers to produce it, with supporting extension programs in the way of its cultivation to profit of the results of these researches.

3- Raising the farm price of the Soybean crop, where the import price of the Soybean oil is reaching its price in Egypt, which affect on delivering the Soybean to the local factories.

4- Using the areas that one not cultivated by rice in cultivating Soybean instead of cultivating in with Maize.

(3.24)

$$
3.71-\log X_{4}+5.61 \log X_{5}-1.13 \log X_{6}
$$

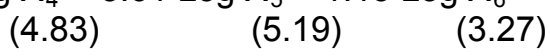

Where

adj $\mathrm{r}^{2}=0.88 \mathrm{~F}=14.27$

The double logarithmic form is distinguished that the elasticity is in direct form, it is occurred from the equation that when the raise in the farm price and net revenue for the Soybean and the feddanic costs of Maize by $10 \%$ the more raise in the cultivated area of Soybean by $11.3 \%, 0.2 \%$ and $56 \%$ sequently, also

\section{REFERENCES}

1) Hamdy El-Sawalhy, et al., : " Economic study of production and consumption of edible oils in Egypt", Egypt. J. of appl. Sci., 10 (10), Oct. (1995).

2) Ministry of agric. and land reclaim. - central administration of agric. Economy and statistics: unpublished data.

3) Ministry of social solidarity , oil administration unpublished data.

4) Mohy Eldin Elbigawy and Yosry Abo-El-khair: " An Economic study for production and consumption of edible oils in the Arab countries", Egyptian Journal of Agricultural Economic Vol. (15) No. (3) September 2005

5) The electronic site of the central agency of mobilization and statistics authority.

6) Thoraya Farid: " An economic study of vegetable oils in Egypt, Egyptian Journal of Agricultural Economic Vol. (14) No. (2) june (2004). 